\title{
Academic librarians and social justice A call to microactivism
}

W

ithin one springtime week, two students told me they were so broke they were skipping meals. I was nine months into my first full-time academic librarian gig. Before that, I had worked a year and a half as a substitute public librarian, helping patrons fill out their first-ever online job applications on top of recommending their next great read. Those hungry students made my public librarian instincts kick in. After hitting a dead end with my college's student services, I contacted a local hunger relief nonprofit myself and got some Supplemental Nutrition Assistance Program (SNAP) brochures. I posted these strategically around the library, and they continue to disappear quietly into students' backpacks.

I originally came to librarianship with a desire to work with others. To increase their access to information, yes, but also to provide a guide to those secret privileged handshakes in society-housing, employment, digital literacy. When I worked in public libraries, I was distinctly aware of the challenges many of my patrons faced in finding services and making ends meet, in a way that often goes unacknowledged in the academic sphere. Now, as an academic librarian, I see that our drive to teach and research can overshadow awareness of the complex needs and lives of the faculty and students with whom we interact.

As a queer female-bodied person, I'm no stranger to the subtle and ominous workings of systemic oppression. But no matter our individual identities within oppressed communities, we as librarians hold automatic privilege: we are master's degree-holders with keys to the information kingdom. We have a responsibility to use our privilege as allies against the myriad discriminations our patrons face, from homophobia to hunger. And academic librarians can't leave that work only to public librarians.

Libraries and social services-and, I would argue, the pursuit of social justice-are longstanding natural partners. And that natural partnership is becoming more explicit, thanks to the work of librarians like Sara Zettervall, whose concept of Whole Person Librarianship explores the connections between social work and library work. ${ }^{1}$ Students, too, do better when librarians attend to their whole wellbeing—not just their grades.

While librarians like Zettervall and others pursue the potential for changing the world through libraries, many in the academic field are consumed by the momentous workload brought on by understaffing, budget cuts, and tenure pressures, and also overwhelmed by the scale and rhetoric of larger social justice movements. Despite occasional apathy or reticence, though, I've also heard librarians

Rachel Lockman is faculty librarian at Minneapolis Community and Technical College, email: rachel. lockman@minneapolis.edu

(c) 2015 Rachel Lockman 
express feelings of hopelessness and anger in the face of our discrimination-drenched society. One trick to whole-person librarianship is to counter that discrimination, even or especially when it manifests as microaggressions.

Although it has a longer history, the term microaggression gained momentum in academic scholarship about racism in the early 2000s to denote the small ways systemic racism plays out. ${ }^{2}$ Since the term was coined, queer, feminist, and other social justice movements have adopted it, as well. ${ }^{3}$ See, for example, the Microaggressions in Librarianship Tumblr, ${ }^{4}$ which calls out microaggressions in the library profession. Our view of microaggressions may begin with our interactions with colleagues but should expand to encompass our patrons, as well. We are united through the microagressions we and our patrons face in our daily lives, and as librarians, we can use our position of privilege to be allies instead of perpetrators.

Let's start a social justice revolution through our everyday work as academic librarians. The Internet abounds with examples of a new principle: microactivism. ${ }^{5}$ Let's harness microactivism in a library context-in our reference interactions with patrons, in our selection of materials, in our curricula, in our cataloging practices-in every area of our days on the job. In this way, our work can be in dialogue with larger movements and give a nod to public libraries' strengths. Hopefully small-scale activism will act as a gateway drug of sorts, leading to greater librarian involvement in progressive change.

So what can microactivism look like, specifically? In my library, besides our SNAP campaign, we use feminist topics to demonstrate databases during instruction sessions; we provide meeting space in the library for the student Gay Straight Alliance; we design displays based on diverse themes; we purchase materials on diverse topics and from alternative publishers.

Academic librarians can also be microactivists through participation on an insti- tutional level, which builds like-minded communities just like larger social justice movements do. Colleges and universities are rife with committees, and librarians do themselves and their patrons a favor by speaking to their interests on a committee or two. I, for instance, am chair of my college's committee in charge of professional development and diversity initiatives.

These are just a few of the many ways librarians can be microactivists, of course. I have great faith in academic, as well as public, librarians' motivation to do good, and our creativity in finding ways to alleviate systemic oppression. But we face a greater challenge when we work alone, handing out SNAP pamphlets in isolation. Let's take the momentum librarians like Zettervall have created and continue the discussion, form our own community, and build our own movement. In the face of change-averse academic administrations and the behemoth of systemic oppression, let's support each other's micro- and macro-activism.

\section{Notes}

1. See http://mlismsw.wordpress.com /author/sarazet/; http://stkatemlis.blogspot. com/2014/03/whole-person-librarianship -course.html.

2. See Daniel Solorzano, Miguel Ceja, and Tara Yosso's 2000 article in The Journal of Negro Education, "Critical Race Theory, Racial Microaggressions, and Campus Racial Climate: The Experiences of African American College Students."

3. See http://en.wikipedia.org/wiki /Microaggression.

4. See http://lismicroaggressions.tumblr. com.

5. See www.greenawards.com/blog /microactivism-a-million-drops-of-water -make-a-rainstorm and http://firstmonday. org/ojs/index.php/fm/article/view/4653.

\section{Acknowledgement}

Special thanks to Emily Drabinski, Char Booth, and Sara Zettervall for their input. $\boldsymbol{n}$ 